\title{
Landfill Site Suitability Selection Using Geospatial Technology for the Yaounde Metropolitan City and its Environs: Case of Soa Subdivision, Cameroon
}

\author{
Anehmbom Ghoutum, \\ Kongnso Wiylahnyuy Edith, \\ Aloysious Kohtem Lebga, \\ Researchers NIC/Cameroon
}

\begin{abstract}
The inappropriate location of landfill sites is a major call for concern in most urban and peri-urban areas in Africa and Cameroon in particular. Rapid and uncontrolled urbanization, scarcity and skyrocketing prices of urban land as well as lack of proper law enforcement due to high corruption causes the population to extend their settlements rapidly into areas where landfill sites are implanted. The objective of this paper is to propose a new landfill site for the Yaounde metropolitan city and its environs based on accepted norms. To attain this, 110 questionnaires were randomly administered to 99 households; satellite image processing, GIS multi criteria analysis with weighted overlay and the analytical hierarchy process were used to produce a suitability map. The outcome shows that human implantation covers $29 \%$ of the total surface area within $500 \mathrm{~m}$ radius around the landfill with $85 \%$ of its households affected health wise. Results also portray that the suitable and most suitable areas cover $56.6 \%$ and $16.9 \%$ whereas the unsuitable and less suitable areas cover $4.5 \%$ and $22 \%$. The environmentally healthy suitable and most suitable sites were selected along the eastern and northern parts of Soa which is relatively accessible to the Yaounde central town.
\end{abstract}

Keywords: Landfill Site, Remote Sensing, GIS, Weighted Overlay, AHP, Yaounde

\section{Introduction}

Waste management started right back in the early days of man's life. Today it is a global major problem which preoccupies both developed and developing countries. However, it is more severe in most cities of developing countries where increased urbanization, poor planning and lack of adequate 
resources contribute to the poor state of municipal solid waste management (Shamim et al, 2014). In addition to this is the lack of technical knowhow in managing complex waste disposal scenarios. Some problems associated to poor waste management include diseases transmission, fire hazards, odor, atmospheric/water pollution and public nuisance.

The Basel convention defines waste as "Substances or objects which are disposed or are intended to be disposed or are required to be disposed of by the provisions of national laws" (UNEP, 2004).

In regard to waste management, proper selection of waste disposal site must be executed in order to develop a safe and healthy environment. The waste must be isolated so that there is no unpleasant risk to the inhabitants or environment (Olusina et al, 2014). Though different tools and techniques are being developed for selection of waste disposal site, landfill is the most common method used in many countries Ayo et al (2011). These landfills are always located far away from human settlement to avoid the nuisance associated with it. However, in most African cities uncontrolled urbanization, scarcity and skyrocketing prices of urban land as well as lack of proper law enforcement due to high corruption causes the population to extend their settlements rapidly into the areas where these landfill sites are implanted. This is as well the case of the Nkolfoulou Soa landfill where urban sprawl, rapid population growth rate and poor housing planning have brought human settlement around this area. Therefore, the allegation of $500 \mathrm{~m}$ distance of landfill sites away from buildup proposed by Ayo et al (2011) constitutes one of the hypothesis of this study which shall be tested for its applicability in Yaounde or not.

In modern times, finding a site to locate undesirable facilities is becoming a significant problem in the planning sector (Erkut et al, 1991). Landfill site selection is described by Zamorano et al, 2008 as a complex process involving social, environmental and technical parameters as well as government regulations which requires the processing of a massive amount of spatial data.

In order to alleviate this problem, integrating GIS and remote sensing techniques to select the best possible solid wastes dumping area is a recent essential technology (Tirusew et al, 2013). This requires a number of factors put together, processed and analysed properly in one system. Many researchers who have applied GIS and Remote sensing successfully in solid waste disposal site suitability selection including Zamorono et al. 2008, Nishanth et al. 2010, Başak, 2004, Kanchanabhan et al. 2016, Katpatal et Rama Rao 2011, Pandey, 2012, Koushik, 2014, Sunil et al. 2012, Yesilnacar et al. 2012, Shukla, 2016 have pointed out that the selection criteria should consider and combine soil types, slopes, surface water, geology, land use and 
road networks. This notwithstanding, the factors used in most analysis is usually also dependent upon the availability of data.

The objective of this paper is to use remote sensing, GIS and multicriteria techniques to determine if the location of the present landfill is a suitable site and if contrary what may be the risk coefficient on health issues. In like manner, using the same resources and knowledge, we seek to make proposals on ideal/ suitable landfill sites to mitigate the challenges of the current situation. In this way we hope to add verifiable knowledge that would assist decision makers and policy formulators to drive the necessary processes for the timely attainment of sustainable development goals number 3 which is good health and wellbeing for all.

\section{Study Area}

Soa is one amongst the eight sub-divisions which make up the Mefou afamba division situated in the center region of Cameroon. It lies west of this division situataed between latitudes $4^{\circ} 8^{\prime} 30^{\prime \prime}$ and $4^{\circ} 52^{\prime} 0^{\prime \prime}$ North and longitudes $11^{\circ} 29^{\prime} 30^{\prime \prime}$ and $11^{\circ} 39^{\prime} 30^{\prime \prime}$ east (Figure 1). It has a total population of 30588 following the 2005 census and occupies a total surface area of 275 $\mathrm{km}^{2}$ with an average elevation of $700 \mathrm{~m}$. Soa a neighborhood of Yaounde also experiences the classical Guinea equatorial climate with four seasons as follows: long dry season (November to March); long rainy season (March to June); short dry season (July to August); and the short rainy season (September to November) with an average annual rainfall of about $1700 \mathrm{~mm}$ (Humphrey et al, 2015). The temperature lies between $23^{\circ}$ and $25^{\circ} \mathrm{C}$.

The Nkolfoulou landfill site is located in this sub-division which serves as the recipient of garbage from major towns within the Mfoundi division including the entire Yaounde/Soa agglomeration. Studies have proven that most landfill sites are located far away from city areas. This was also the case of the Nkolfoulou site during its implantation but recently the continuous upsurge in population growth, unplanned urbanization and rising prices of urban land within the Mfoundi division has transformed the land use of this study area making it environmentally not conducive for the population living around this vicinity. 


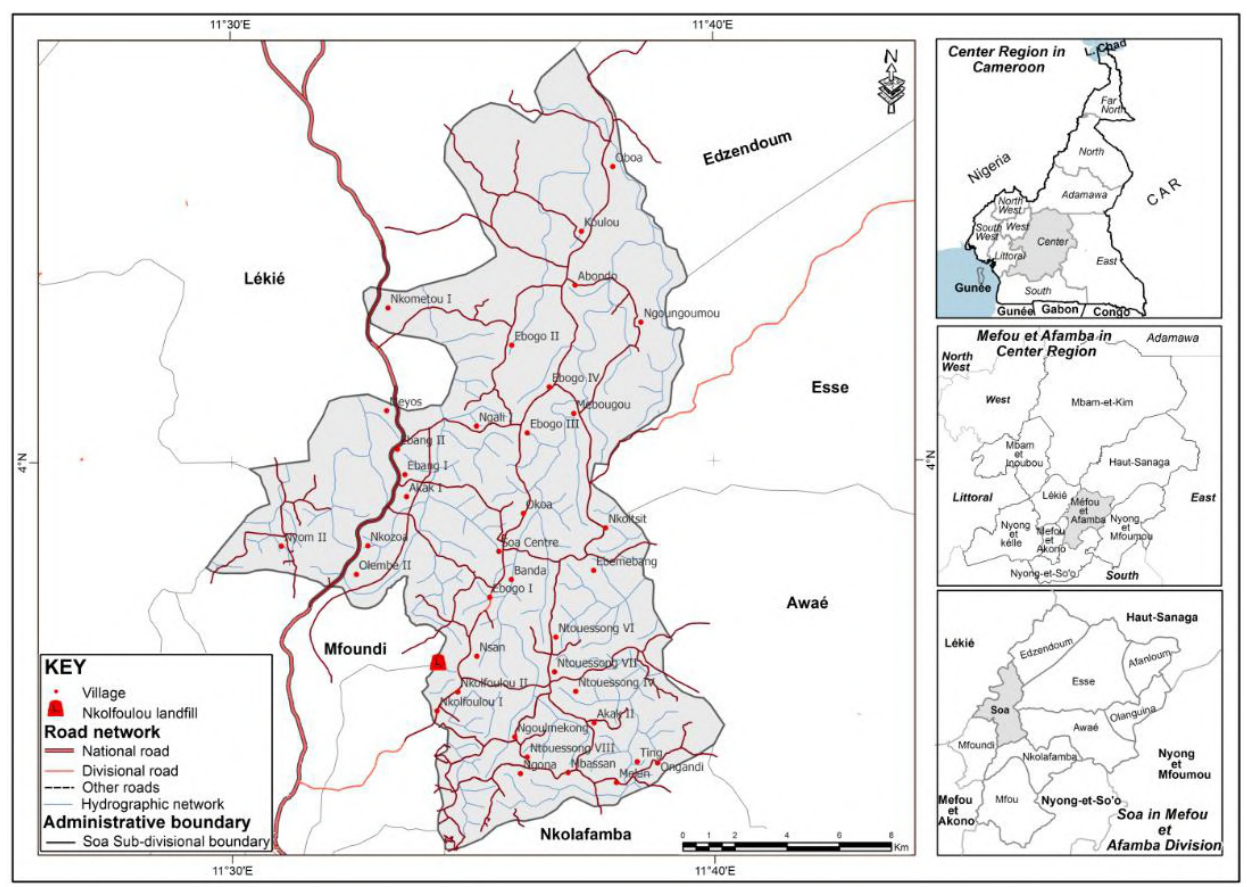

Fig 1: Location map of Soa Sub-division

Source: Extract from the administrative map of Cameroon by the National Institute of Cartography (NIC), Google earth satellite image and fieldwork

\section{Methodology}

This work was executed in three phases. The objective of the first stage was to show the unsuitable location of the present landfill site; meanwhile the second phase consisted in showing the population that has been affected health wise by this landfill. Finally the last stage involved the sitting of suitable sites for future landfill implantation.

To materialize the first stage, in ArcGIS a map was produced with a buffer of 500m over buildup area gotten from Java open street map (JOSM) to show the settlement exposed to the impacts of the landfill. For the same purpose, the 500m buffer was converted into a kmz file in QuantumGIS 2.7 and the 2017 Google image snipped to give a clear picture of the vulnerable population.

Concerning the second phase, one hundred and ten questionnaires were distributed to 99 households using a stratified random sampling technique. The questions were directly related to the effects of the presence of the landfill. This data was used to show the population that has been affected by this landfill.

In regard to the third phase which consisted in sitting suitable areas for future landfill implantation, an extensive evaluation of data was used in order to identify the optimum site for waste disposal. The geographic coordinates 
(longitudes and latitudes) of markets, churches, schools, mosques, were captured on the field with the aid of a GPS and used to create a layer of protected areas in ArcGIS. This was done based on good mastery of the terrain. Landsat image of 2018 was derived from USSG from which a land use map made up of four classes as in build up, farm land, shrubs and forest was derived after classification was implemented in Erdas IMAGINE 2015. The Digital Elevation Model was extracted from SRTM of $30 \mathrm{~m}$ resolution in order to produce a slope map. Meanwhile roads and water courses were gotten from Java open street mapping.

Multiple ring buffers were done on roads, water courses and protected areas and were later converted to raster layers so as to facilitate the weighted overlay analysis. The distances used in creating the buffers were based on literature derived from similar studies.

All three raster layers in addition to the slope and land use layers were reclassified each into four classes of particular values representing different suitability levels with $1 \mathrm{~s}$ as unsuitable, $2 \mathrm{~s}$ as less suitable, $3 \mathrm{~s}$ as suitable and $4 \mathrm{~s}$ as most suitable. Weights gotten from the Analytical Hierarchy process developed by SAATY in 1980 through pairwise comparison were assigned to the five reclassified raster layers and all were overlaid with the use of the weighted overlay tool to generate a suitability map of the study area.

\section{Results and Discussions}

\section{a) Inappropriate location of Soa landfill}

The inappropriate position of the Soa landfill site remains a call for concern to many stakeholders. The continuous encroachment of settlements into and around the landfill site is due to rapid and uncontrolled urbanization and rising prices of urban land. As a result, out of 687 hectares which makes up the $500 \mathrm{~m}$ radius around this landfill site, 200 hectares $(29 \%)$ of the $500 \mathrm{~m}$ radium has been occupied by human settlement. Figure 2 and 3 shows the inappropriate location of the present landfill site with settlements within $500 \mathrm{~m}$ radius. This has rendered this site unsuitable because its immediate effect on environmental pollution is already having its toll on the population living around this vicinity. As a result, it's imperative for new landfill sites to be located so as to avoid both health and environmental consequences. 


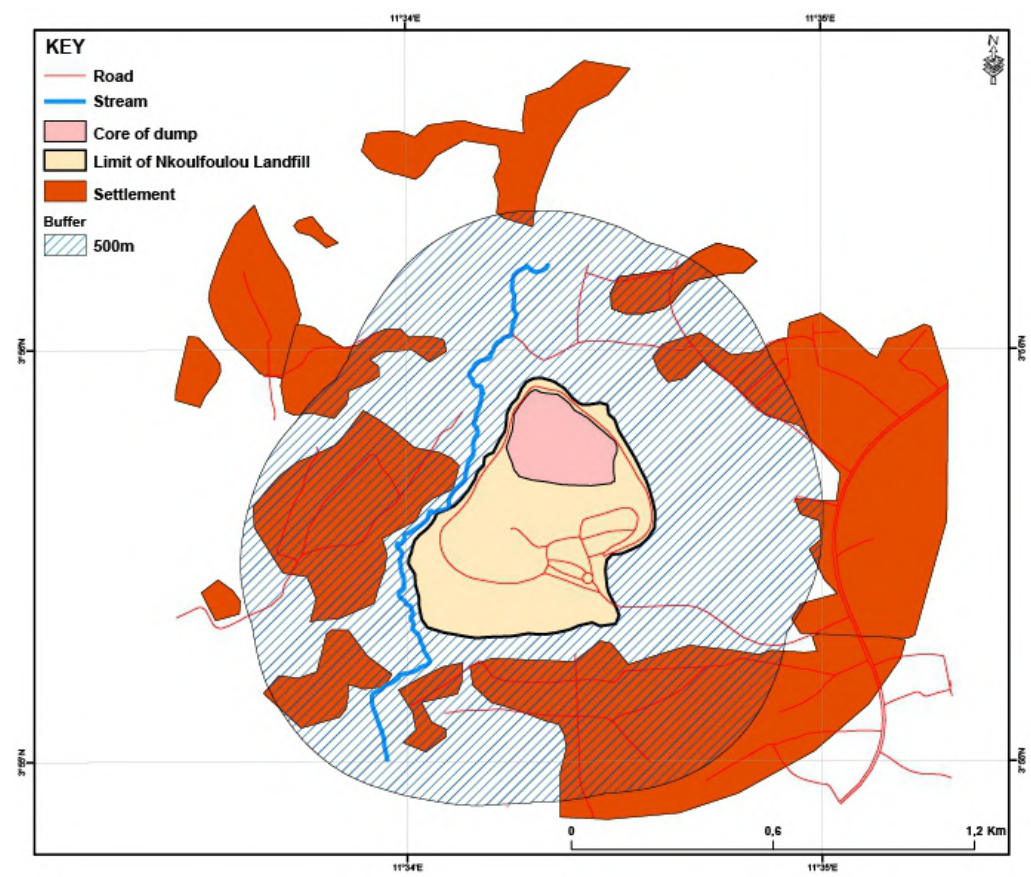

Fig 2: Map showing 500 meter buffer around the Nkolfoulou Landfill

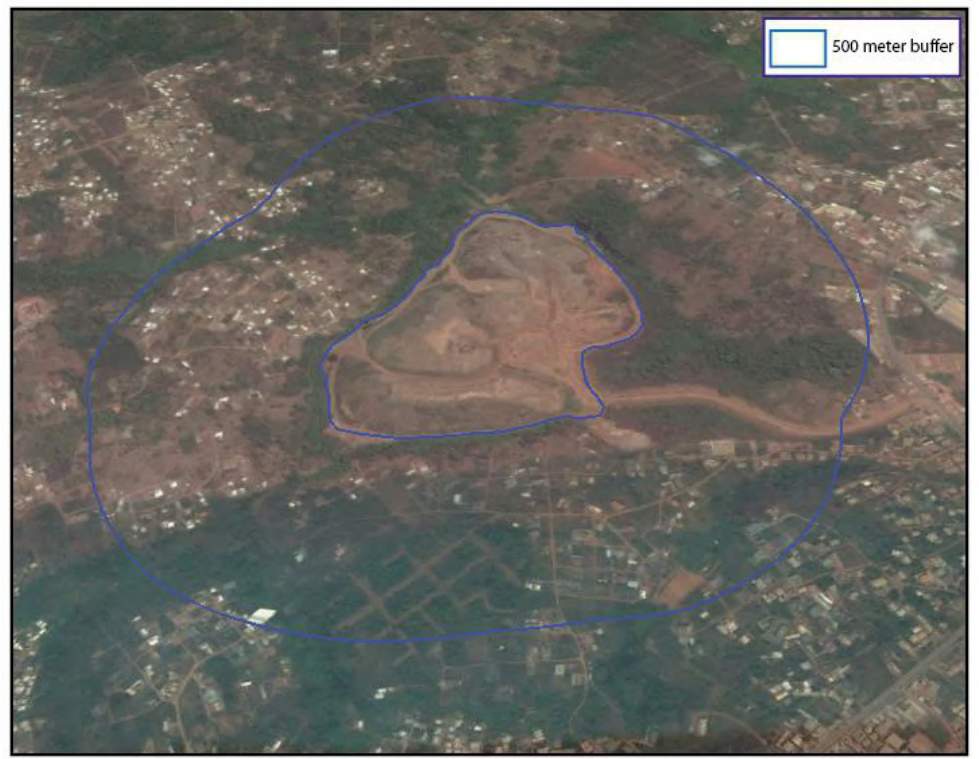

Fig 3: Google Earth image showing settlement within 500m radius vulnerable to landfill impacts

\section{b) Health effects}

Nkolfoulou landfill site neighborhood is presently witnessing an increasing human implantation. This is visible with houses sharing boundaries 
with this landfill site and some spotted just a kilometer from the core dumping site. The aftermath of this isn't only limited to the health conditions of these inhabitants but equally to the percentage of income spent in order to maintain or regain their health. About $85 \%$ of households investigated around this landfill site are affected with at least one disease linked to this environmental imbalance and $15 \%$ remain indifferent to any contamination. In addition, 40 respondents spend closed to $30 \%$ of their household income on health related issue with malaria and waterborne diseases topping their chart. Figure 4 shows the results of the questionnaires administered to 99 randomly selected households located within 500m radius around this landfill site and its influence on their health condition.

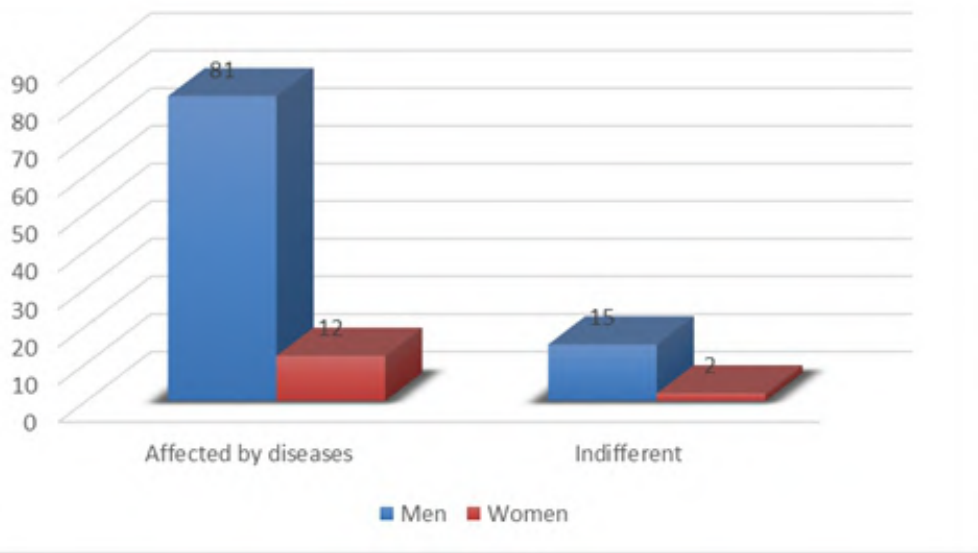

Fig 4: Health Effects of the Nkolfoulou Landfill site on household

\section{c) Identification of suitable site}

\section{i. Creation of thematic raster maps}

In order to facilitate the overlaying process, standardization of the data set was done respecting a common range between 1-4 as follows: $1=$ unsuitable, $2=$ less suitable, $3=$ suitable and $4=$ most suitable.

- Slope

Slope which is defined as the first derivative of a DEM represents the rate of elevation change for each DEM cell with output measurement values either in degree or percentage rise. Literature from many sources has proven that neither very high slopes nor flat terrains are suitable for landfill sitting. According to Olusina et al. (2014), low slope is required to minimize erosion and water runoff as well as to facilitate the construction of the site to be much easier and with lower costs. Meanwhile other research has proven that high slope increases the risk of pollution and therefore is not suitable for landfill implantation. In regard to this, the slope map which was generated using SRTM of $30 \mathrm{~m}$ resolution was classified into four groups based on their 
degrees. Areas with slopes of $>25^{\circ}$ were considered as unsuitable, $0-5$ as less suitable, 15-25 as suitable and 5-15 as most suitable as shown in figure 5. In this study area, $60.2 \%$ falls under the class of $5-15^{\circ}, 2.8 \%$ under $25-68^{\circ}$ meanwhile $18.8 \%$ and $18.2 \%$ falls under $0-5^{\circ}$ and $15-25^{\circ}$ classes respectively as shown in table 1 . This results show that in respect to slope, more than half of the total surface area of our case study is suitable for landfill implantation.

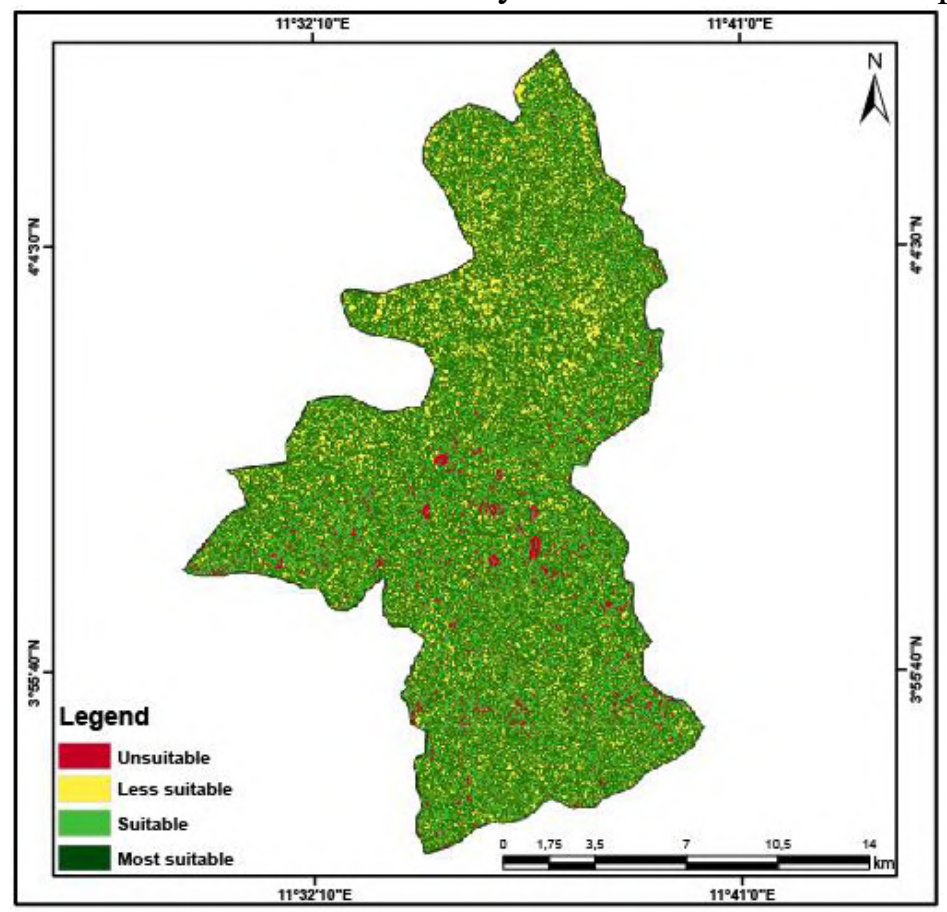

Fig 5: Slope classification

Table 1: Suitability value and coverage of Slope

\begin{tabular}{|c|c|c|c|c|}
\hline $\begin{array}{c}\text { Slope in } \\
\text { degree }\end{array}$ & Suitability level & Value & Area $\left(\mathbf{k m}^{\mathbf{2})}\right.$ & Area (\%) \\
\hline $0-5$ & Less suitable & 2 & 51.7 & 18.8 \\
\hline $5-15$ & Most suitable & 4 & 165.3 & 60.1 \\
\hline $15-25$ & Suitable & 3 & 50.3 & 18.3 \\
\hline $25-68$ & Unsuitable & 1 & 7.7 & 2.8 \\
\hline
\end{tabular}

- Distances to Water courses

Rivers and Streams are great natural resources to most African communities with Soa locality not being an exemption because of its domestic usage. Furthermore it is very important for the vital role it plays in ecological balance to human activities. Taking this into consideration, landfill should not be placed close to these resources in order to mitigate ground water pollution. Rivers can be endangered by the landfill because of leachate thus bringing a great pollution to the river (Olusina et al, 2014). This study area is made up of 
a river and of multiple streams running across it. Hence in order to avoid water pollution, buffer zones of 500, 700, 1000 meters were created around these water surfaces and classified into four classes as shown in figure 6 . The $0-500$ meter buffer was considered as unsuitable, $500-700 \mathrm{~m}$ buffer as less suitable, $700-1500 \mathrm{~m}$ buffer as suitable and 1500-3000 buffer as the most suitable sites with area coverage as seen on table 2 .

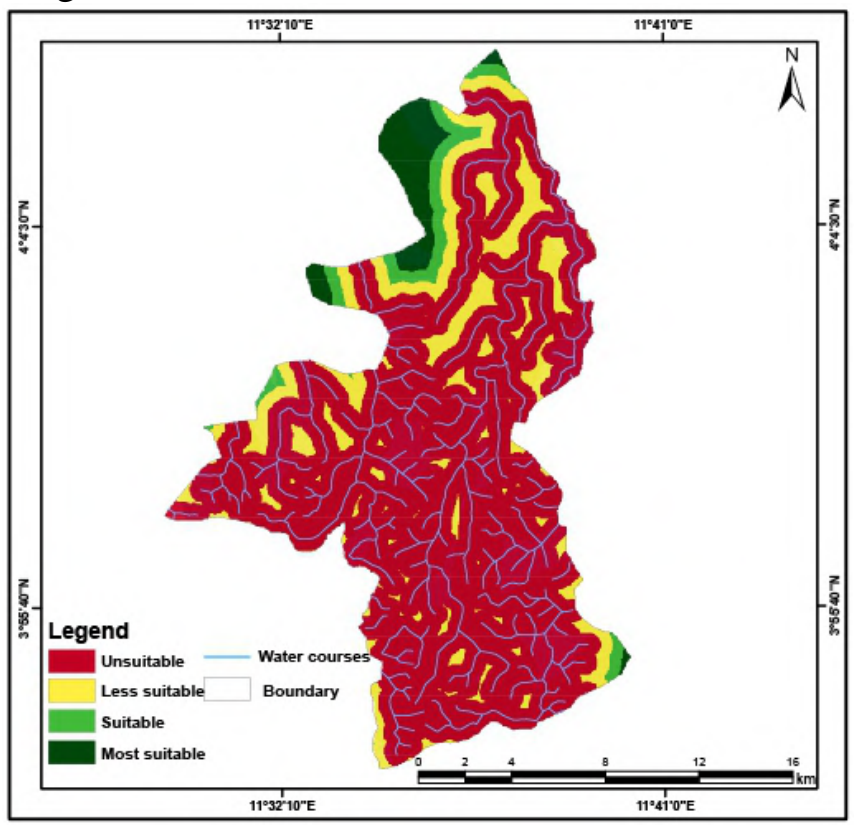

Fig 6: Water courses classification

Table 2: Suitability value and coverage of water courses

\begin{tabular}{|c|c|c|c|c|}
\hline Water courses & Suitability level & Value & Area $\left(\mathbf{k m}^{2}\right)$ & Area (\%) \\
\hline 500 & Unsuitable & 1 & 216.9 & 78.9 \\
\hline 700 & Less suitable & 2 & 37.1 & 13.5 \\
\hline 1500 & Suitable & 3 & 9.3 & 3.4 \\
\hline 3000 & Most suitable & 4 & 11.7 & 4.3 \\
\hline
\end{tabular}

- Distances to roads

For easy accessibility, landfills must always be situated in favour to road proximity so as not to compromise cost for waste collection and transportation. This notwithstanding it shouldn't be located too close to the road so as to prevent environmental pollution and aesthetic damage. Using ArcGIS, multi ring buffer zones of roads with 300, 500, 1000 and 2500 meters were created. Only the tarred roads and some important untarred but motorable roads were used. We considered $0-300 \mathrm{~m}$ buffer as unsuitable and $300-500 \mathrm{~m}$ buffer as most suitable whereas $500-1000 \mathrm{~m}$ buffer as suitable and $1000-2500$ buffer as less suitable for waste disposal site location. See figure 7 and table 3 
for more details. These criteria were adapted from that of Mipun (2015) and Balasooriya (2014).

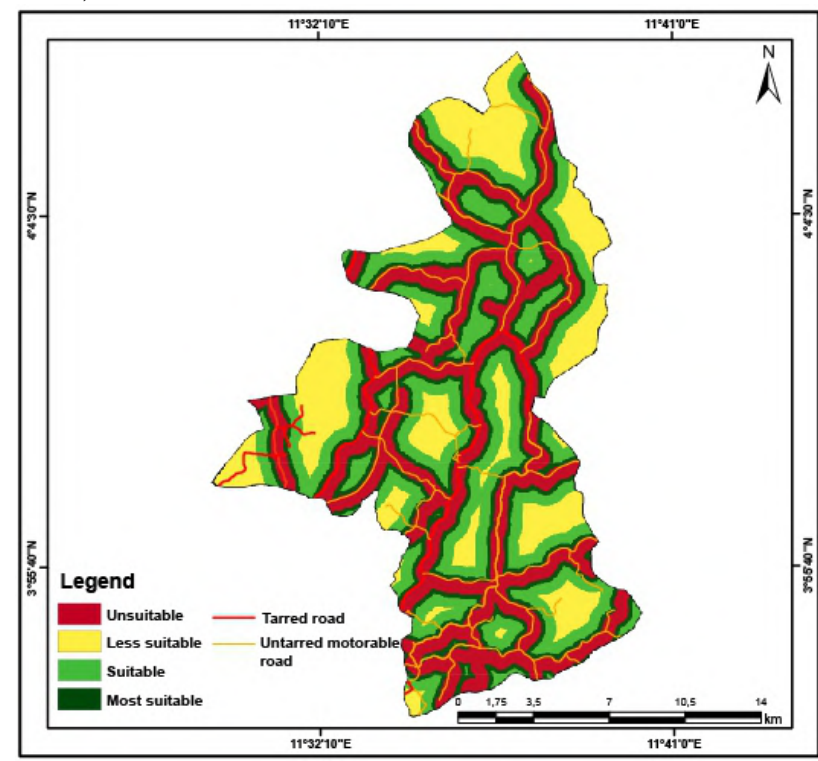

Fig 7: Road classification

Table 3: Suitability value and coverage of roads

\begin{tabular}{|c|c|c|c|c|}
\hline Roads & Suitability level & Value & Area $\left(\mathbf{k m}^{2}\right)$ & Area (\%) \\
\hline 300 & Unsuitable & 1 & 88.4 & 32.1 \\
\hline 500 & Most suitable & 4 & 48.3 & 17.6 \\
\hline 1000 & Suitable & 3 & 79.8 & 29 \\
\hline 2500 & Less suitable & 2 & 58.5 & 21.3 \\
\hline
\end{tabular}

- Land use/landcover

In this study, landsat image of $30 \mathrm{~m}$ resolution was used to classify this zone under four classes which consisted of build up, farmland, shrubs and forest depending on the usage of the zone. Regarded as the major criteria for this analysis, classification was very useful in determining the suitable and most suitable sites. Though it is advisable as gathered from most literature to locate landfills in bare or barren lands and grasslands or shrubs (Tirusew et al, 2013, Balasooriya et al, 2014), nevertheless due to the absence of bare land in our study area, we classified the shrubs as most suitable, forest suitable, farmland less suitable and build up area as unsuitable as shown in figure 8 . We underline that the absence of both barren land and wasteland, coupled with the fact that the present landfill site is unsuitable, constrained us to classify forest as suitable due to the peculiarity of this study area. Their surface areas were calculated as shown in table 4 . We strongly advice the decision makers to avoid the forest areas for the new landfill. 


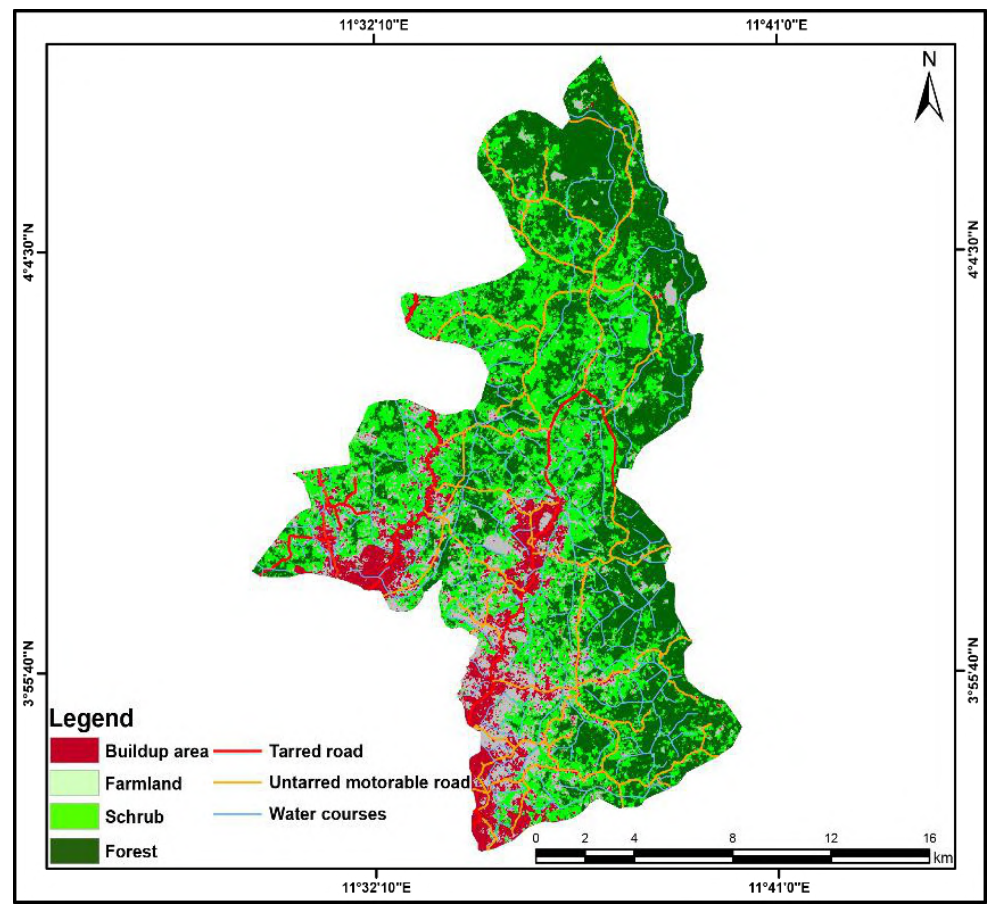

Fig 8: Land use/Landcover Classification

Table 4: Suitability value and coverage of Land use

\begin{tabular}{|c|c|c|c|c|}
\hline Classes & Suitability level & Value & Area $\left(\mathbf{k m}^{\mathbf{2}}\right)$ & Area (\%) \\
\hline Buildup areas & Unsuitable & 1 & 30.6 & 11.1 \\
\hline Farmland & Less suitable & 2 & 37.4 & 13.6 \\
\hline Forest & Suitable & 3 & 114.1 & 41.5 \\
\hline Shrub & Most suitable & 4 & 92.9 & 33.8 \\
\hline
\end{tabular}

- Distances to protected areas

Just like Tirusew et al, 2013, this study considered churches, markets, schools as protected areas which need to be located away from landfill sites because of the presence of high population concentration in these areas. Buffer zones of the following classes were created: 0-500 as unsuitable, 500-1000 as less suitable, 1000-1500 as suitable and 1500-5000 as most suitable as shown in figure 9. This means that the suitability of a landfill site increases as the presence of population decreases. Table 5 shows the coverage of each suitability level. 


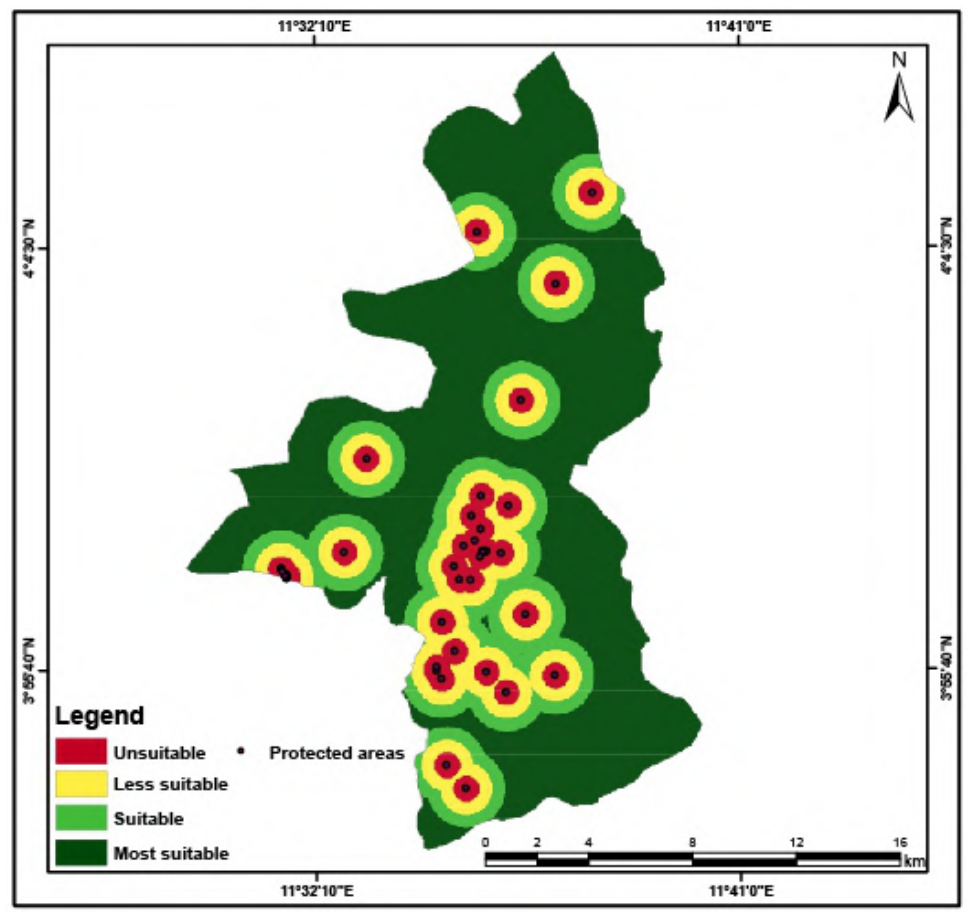

Fig 9: Protected area classification

Table 5: Suitability value and coverage of protected area

\begin{tabular}{|c|c|c|c|c|}
\hline Roads & $\begin{array}{c}\text { Suitability } \\
\text { level }\end{array}$ & Value & Area $\left(\mathbf{k m}^{2}\right)$ & Area (\%) \\
\hline 500 & Unsuitable & 1 & 19.8 & 7.2 \\
\hline 1000 & Less suitable & 2 & 39.8 & 14.5 \\
\hline 1500 & Suitable & 3 & 46 & 16.7 \\
\hline 5000 & Most suitable & 4 & 169.4 & 61.6 \\
\hline
\end{tabular}

\section{ii. Analytical Hierarchy Process (AHP)}

The Analytical Hierarchy Process following the logic produced by Saaty was used to derive the weights for each element. This method consisted in ranking the elements according to their relative importance in the sitting process using the pairwise comparison matrix of 9 continuous points scale (table 6). From this, the eigenvector weight was derived and presented in percentages as seen in table 7 .

Table 6: Pairwise comparison

\begin{tabular}{|c|c|c|c|c|c|}
\hline & $\begin{array}{c}\text { Landuse/ } \\
\text { Landcover }\end{array}$ & Protected area & Road & Water course & Slope \\
\hline Landuse/ Landcover & 1 & 3 & 5 & 7 & 9 \\
\hline Protected area & 0,33 & 1 & 3 & 3 & 8 \\
\hline Road & 0,2 & 0,33 & 1 & 3 & 7 \\
\hline Water course & 0,14 & 0,33 & 0,33 & 1 & 7 \\
\hline Slope & 0,11 & 0,12 & 0,14 & 0,14 & 1 \\
\hline
\end{tabular}


Table 7: Percentages of eigenvector weight

\begin{tabular}{|l|c|c|}
\hline \multicolumn{1}{|c|}{ Element } & Eigenvector weight & Percentage weight \\
\hline Landuse/ Landcover & 0.49 & 49 \\
\hline Protected area & 0.23 & 23 \\
\hline Road & 0.15 & 15 \\
\hline Water course & 0.10 & 10 \\
\hline Slope & 0.03 & 3 \\
\hline
\end{tabular}

\section{iii. Weightage overlay Analysis}

The weightage overlay tool in ArcGIS is one of the most known and used tool in solving suitability problems. The weights derived from the AHP were attributed to their respective raster layers and with the use of the weightage overlay tool they were all weighted together to produce the suitability map (figure 10). Since each cell of each input raster had already been reclassified on an evaluation scale of 1 - 4, this was maintained to produce the final suitability map where 1 represented the lowest or unsuitable areas and 4 the highest or most suitable areas.

Results from the suitability map demonstrates that the unsuitable area covers $12.5 \mathrm{~km}^{2}$, less suitable covers $62.7 \mathrm{~km}^{2}$, suitable covers $154.8 \mathrm{~km}^{2}$ and the most suitable area covers $45 \mathrm{~km}^{2}$ (table 8 ). Though this indicates that the suitable area covers more than half of the total surface area, the most appropriate locations will be that closest to the Mfoundi division so as to lighten transportation cost. It was based on this notion that the four sites shown in figure 11 were chosen. Table 9 shows surface areas of these suggested sites.

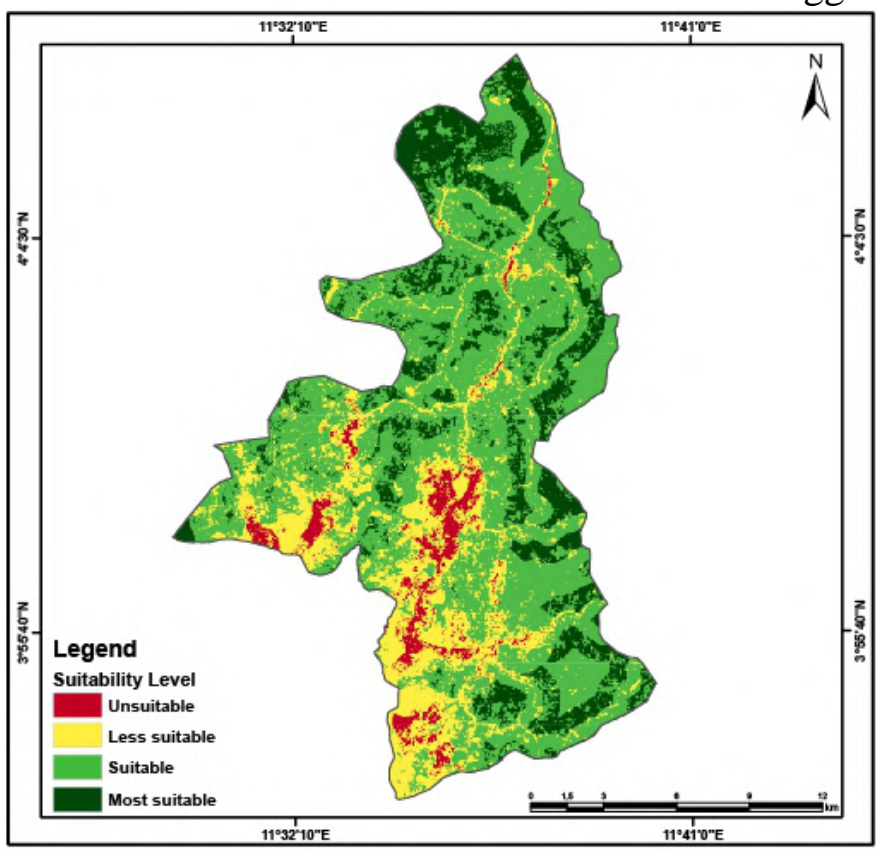

Fig 10: Suitability map 
Table 8: Suitability area coverage

\begin{tabular}{|c|c|c|c|}
\hline Suitability level & Value & Area $\left(\mathbf{k m}^{2}\right)$ & Area (\%) \\
\hline Unsuitable & 1 & 12.3 & 4.5 \\
\hline Less suitable & 2 & 60.5 & 22 \\
\hline Suitable & 3 & 155.7 & 56.6 \\
\hline Most suitable & 4 & 46.5 & 16.9 \\
\hline
\end{tabular}

Table 9: Suggested sites and coverage for future landfill sites

\begin{tabular}{|c|c|c|}
\hline \multirow{3}{*}{$\begin{array}{c}\text { Most suitable } \\
\text { sites }\end{array}$} & Sites & Area (Ha) \\
\cline { 2 - 3 } & 1 & 83.1 \\
\cline { 2 - 3 } & 2 & 77.1 \\
\hline \multirow{3}{*}{ Suitable sites } & 3 & 62.5 \\
\cline { 2 - 3 } & 1 & 98.9 \\
\cline { 2 - 3 } & 2 & 91.8 \\
\hline
\end{tabular}

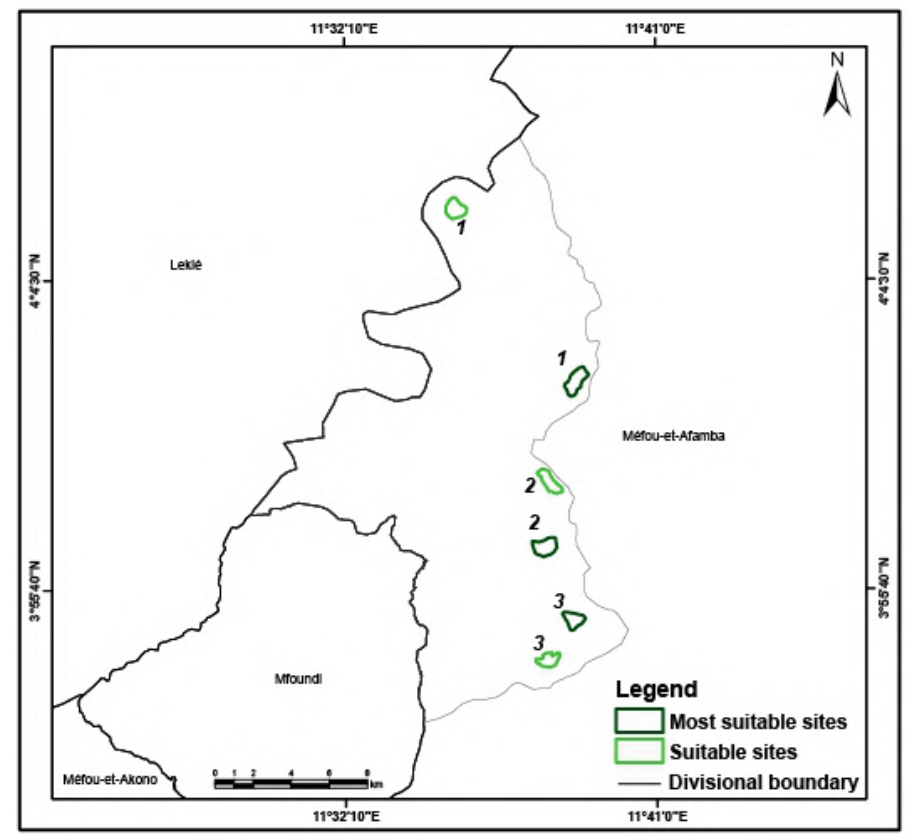

Fig 11: Suitable and Most suitable sites

\section{Conclusion}

This paper has shown that the present location of the Nkolfoulou landfill site in Soa is inappropriate. To alleviate this problem, this work integrated the use of GIS and remote sensing as effective and best decision support tools to locate suitable sites for waste disposal. Seven out of ten households chosen randomly around the Nkolfoulou landfill site suffered from diseases linked to this environmental imbalance and three remained indifferent. A diversified array of data was used for this analysis taking into 
consideration slope, water courses, land use, protected areas and road. With the use of AHP method of pairwise comparison analysis and weighted overlay tool in ArcGIS a suitability map of the study area was produced. This map was classified under four classes made up of unsuitable, less suitable, suitable and most suitable. The results portrays that the suitable and most suitable areas covers $56.6 \%$ and $16.9 \%$ whereas the unsuitable and less suitable areas covers $4.5 \%$ and $22 \%$. All the suitable and most suitable sites selected are located far from environmental interest areas like streams, settlements where population is concentrated so as to reduce environmental and health effects. In order to avoid high transportation cost, the suitable and most suitable sites were selected along the eastern and northern parts of Soa which is relatively accessible to the Yaounde central town. Though this paper portrays GIS and Remote sensing as powerful decision making and problem solving tools in sitting suitable sites for waste disposal, the role to be played by the government and city planners is more vital. This is because if urban planning is not implemented and strictly controlled, population will still turn to reside around any newly created landfill. This therefore means that city planners on their own part should carve out such areas within a certain perimeter restricting it from population settlement so as to achieve a long lasting solution. We stress that the absence of both barren land and wasteland constrained us to classify forest as suitable due to the distinctiveness of this study area. We strongly advice the decision makers to avoid the forest areas for the new landfill.

\section{References:}

1. Ayo , B., \& Busu, I. (2011). Selection of Landfill Sites for Solid Waste Treatment in Damaturu Town-Using GIS Techniques. Journal of Environmental Protection, 2, 1-10. Retrieved 9 10, 2018, from http://www.SciRP.org/journal/jep

2. Balasooriya, B. M., Vithanage, M., Nawarathna, N. J., Ken , K., Zhang, M., Herath, G. B., \& Mowjood, M. I. (2014). Solid Waste Disposal Site Selection for Kandy District, Sri Lanka Integrating GIS and Risk Assessment. International Journal of Scientific and Research Publications, 4(10), 1-6.

3. Başak, Ş. (2004). Landfill site selection by using Geographic Information Systems: Master's degree thesis in Geological Engineering of the Graduate School of Natural and Applied Sciences of the Middle East Technical University.

4. Erkut, E., \& Moran, S. R. (1991). Locating obnoxious facilities in the public sector: An application of the analytic hierarchy process to municipal landfill siting decisions. Socio-Economic Planning Sciences, 25(2), 89-102. doi:10.1016/0038-0121(91)90007-E 
5. Humphrey, N. N., K, F., Feumba, R., \& Takem , M. B.-M. (2015). Urbanisation, wetland retreat and heat island development in Yaounde, Cameroon. UGEC Viewpoints.

6. Kanchanabhan, T., Mohaideen, A. J., Srinivasan, S., \& Lenin, K. S. (2016). Optimum municipal solid waste collection using Geographical Information System (GIS) and vehicle tracking for Pallavapuram municipality. Waste Management \& Research, 23(3), 323-339. doi:10.1177/0734242X10366272

7. Katpatal, Y. B., \& Rama Rao, B. V. (2011). Urban Spatial Decision Support System for Municipal Solid Waste Management of Nagpur Urban Area Using High-Resolution Satellite Data and Geographic Information System. Journal of Urban Planning and Development, 137(1), 65-76. doi:10.1061/(asce)up.1943-5444.0000043

8. Koushik, P., Amit, D., \& A, P. K. (2014). A comprehensive study on landfill site selection for Kolkata City, India. Journal of the Air \& Waste Management Association, 846-861. doi:10.1080/10962247.2014.896834

9. Mipun, B. S., Hazarika, R., Mondal, M., \& Mukhopadhyay, S. (2015). Solid Waste Management in Greater Shillong Planning Area (GSPA) Using Spatial Multi-Criteria Decision Analysis for Site Suitability Assessment. The International Archives of the Photogrammetry, Remote Sensing and Spatial Information Sciences, XL-7/W3, 657662. doi:10.5194/isprsarchives-XL-7-W3-657-2015

10. Nishanth, T., Prakash , M. N., \& Vijith, H. (2010). Suitable site determination for urban solid waste disposal using GIS and Remote sensing techniques in Kottayam Municipality, India. International Journal Of Geomatics And Geosciences, 1(2), 197-210.

11. Olusina, J. O., \& Shyllon, D. O. (2014). Suitability Analysis in Determining Optimal Landfill Location using Multi-Criteria Evaluation (MCE), GIS \& Remote Sensing. International Journal of Computational Engineering Research (IJCER), 4(6), 7-20. Retrieved from http://www.ijceronline.com

12. Pandey, D. (2012). Selection of prospective waste disposal sites for Gondia Municipal Council of Maharashtra, India. International journal of Life Sciences Biotechnology and Pharma Research, 1(3), 174-181.

13. Shamim , A. S., \& Muzafar , A. W. (2014). Geospatial Based Approach for Enhancing Environment Sustainability of Srinagar city A Study on Solid Waste Disposal. International Journal of u-and eService, Science and Technology, 7(3), 289-302. doi:10.14257/ijunesst.2014.7.3.25 
14. Shukla, R. (2016). Smart waste management. Asian Journal of Pharmaceutical Education and Research, 5(2), 48-54.

15. Sunil , K., \& Izhar, M. H. (2012). Selection of a Landfill Site for Solid Waste Management: An Application of AHP and Spatial Analyst Tool. Indian Society of Remote Sensing. doi:10.1007/s12524-011-0161-8

16. Tirusew , A. E., \& Amare, S. M. (2013). Solid waste dumping site suitability analysis using Geographic Information System (GIS) and Remote Sensing for Bahir Dar Town, North Western Ethiopia. African Journal of Environmental Science and Technology, 7(11), 976-989. doi:10.5897/AJEST2013.1589 United Nations Environmental Programme . (2004).

17. Yesilnacar, I. M., Lütfi , S. M., Başak , Ş. K., \& Vedat , D. (2012). Municipal solid waste landfill site selection for the city of ŞanliurfaTurkey: an example using MCDA integrated with GIS. International Journal of Digital Earth, 5(2), 147-164. doi:10.1080/17538947.2011.583993

18. Zamorano, M., Emilio , M., \& Alvaro, H. (2008). Evaluation of a municipal landfill site in Southern Spain with GIS-aided methodology. Journal of Hazardous Materials. doi:10.1016/j.jhazmat.2008.03.023 